\title{
Unilateral diaphragmatic palsy may be a rare but important complication of elective direct current cardioversion
}

\author{
Cyrus Daneshvar, Victoria M Tippett, Christopher G Wathen
}

Department of Respiratory Medicine, Wycombe Hospital, High Wycombe, UK

Correspondence to Dr Victoria M Tippett, victoriatippett@doctors.org.uk

\section{DESCRIPTION}

A 69-year-old man presented with mild, but limiting exertional breathlessness. He had undergone an elective direct current (DC) cardioversion for atrial fibrillation 7 days previously.

A chest radiograph performed by the cardiology team showed a raised right hemi-diaphragm (figure 1). A chest radiograph performed 6 months before had been normal. Symptoms and radiographic changes were persistent at 4 months, and referral to the respiratory team was made. Pleural ultrasonography confirmed a right hemidiaphragmatic paralysis and no sinister cause was identified either clinically or by CT scanning. Pulmonary function tests showed a reduced forced vital capacity of 1.89 litres (50\% predicted). At most recent review 8 months after the initial presentation, the patient's symptoms continued unchanged.

Unilateral diaphragmatic paralysis is a known complication of cardiac surgery and more recently catheter ablation; ${ }^{1}$ however, there are no previous cases reported in the

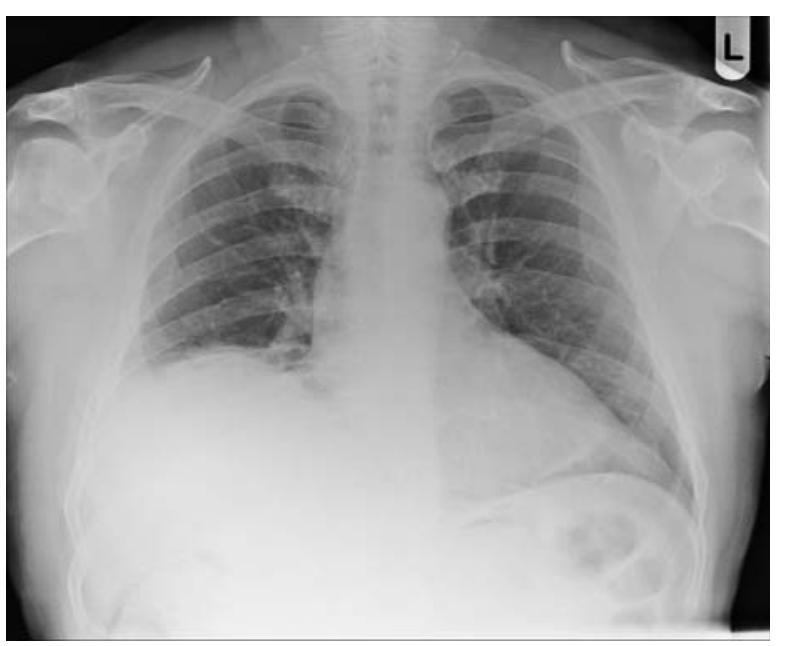

Figure1 Admission chest radiograph showing bilateral apical plombes. literature following DC cardioversion. Possible explanations for the relationship of diaphragmatic paralysis to cardioversion include thermal injury, since phrenic nerve damage may occur at relatively low rises in temperature, ${ }^{2}$ or damage to the right internal mammary artery leading to phrenic nerve infarction. ${ }^{3}$ Embolic phenomena affecting phrenic nerve function cannot be excluded, despite the patient being warfarinised in the period following cardioversion. $^{4}$

Our patient was symptomatic of his condition; however, more than $75 \%$ of patients with unilateral diaphragmatic palsy do not experience symptoms, ${ }^{5}$ which might explain the paucity of previous case reports as chest radiographs are not performed routinely after elective DC cardioversion.

\section{Learning points}

- Breathlessness after direct current (DC) cardioversion may have a non-cardiac cause.

- Unilateral diaphragmatic palsy may be a rare but important complication of DC cardioversion.

Competing interests None

Patient consent Obtained.

\section{REFERENCES}

1. Sacher $\mathbf{F}$, Monahan $\mathrm{KH}$, Thomas SP, et al. Phrenic nerve injury after atrial fibrillation catheter ablation: characterization and outcome in a multicenter study. J Am Coll Cardiol 2006;47:2498-503.

2. Bunch TJ, Bruce GK, Mahapatra $S$, et al. Mechanisms of phrenic nerve injury during radiofrequency ablation at the pulmonary vein orifice. $J$ Cardiovasc Electrophysiol 2005;16:1318-25.

3. O'Brien JW, Johnson SH, Van Steyn SJ, et al. Effects of internal mammary artery dissection on phrenic nerve perfusion and function. Ann Thorac Surg 1991;52:182-8.

4. Singer DE, Albers GW, Dalen JE, et al. Antithrombotic therapy in atrial fibrillation: American College of Chest Physicians Evidence-Based Clinical Practice Guidelines (8th Edition). Chest 2008;133:546S-92S.

5. Elefteriades J, Singh M, Tang $P$, et al. Unilateral diaphragm paralysis: etiology, impact, and natural history. J Cardiovasc Surg (Torino) 2008:49:289-95. 


\section{BMJ Case Reports}

This pdf has been created automatically from the final edited text and images.

Copyright 2012 BMJ Publishing Group. All rights reserved. For permission to reuse any of this content visit http://group.bmj.com/group/rights-licensing/permissions.

BMJ Case Report Fellows may re-use this article for personal use and teaching without any further permission.

Please cite this article as follows (you will need to access the article online to obtain the date of publication).

Daneshvar C, Tippett VM, Wathen CG. Unilateral diaphragmatic palsy may be a rare but important complication of elective direct current cardioversion. BMJ Case Reports 2012;10.1136/bcr-03-2012-6125, Published XXX

Become a Fellow of BMJ Case Reports today and you can:

- Submit as many cases as you like

- Enjoy fast sympathetic peer review and rapid publication of accepted articles

- Access all the published articles

- Re-use any of the published material for personal use and teaching without further permission

For information on Institutional Fellowships contact consortiasales@bmjgroup.com

Visit casereports.bmj.com for more articles like this and to become a Fellow 